\title{
The rs3857059 variant of the SNCA gene is associated with Parkinson's disease in Mexican Mestizos
}

\author{
A variante rs3857059 do gene SNCA é associada à doença de Parkinson em mestiços \\ mexicanos
}

S. Garcia', G. Chavira-Hernández¹, M. P. Gallegos-Arreola², L. Dávila-Maldonado³, F. García Martínez', L. A. Montes Almanza', C. Palma-Flores', P. Mondragón-Terán'1, S. L. Alcaraz Estrada', L. B. López-Hernández'

\begin{abstract}
Among the candidate genes for Parkinson's disease (PD), SNCA has replicated association in different populations. Besides other known mutations in the SNCA gene, the rs3857059 variant has also been linked to various neurodegenerative disorders. Therefore, the aim of the present study was to search for association of this variant and sporadic PD in Mexican Mestizo patients. A case-control study was performed including 241 individuals, 106 patients, and 135 healthy controls. Genotyping was performed using real-time PCR. The rs3857059 variant demonstrated an association with PD in Mexican Mestizos (OR $=2.40, \mathrm{Cl}, 1.1$ to 5.1, $p=0.02)$ under the recessive model. In addition, a gender effect was found for the $G G$ genotype in females ( $O R=1.31, \mathrm{Cl}, 1.01$ to $1.7, \mathrm{p}=0.037$ ). This is the first study to confirm an association of the rs3857059 variant with PD and also to show a gender effect. Our data contribute to the elucidation of the link between rs3857059 and susceptibility to PD observed in the Mexican Mestizo population.
\end{abstract}

Keywords: Parkinson disease; genes, SNCA; genetics.

\section{RESUMO}

Entre genes candidatos para a doença de Parkinson (PD), SNCA foi replicado em diferentes populações. Além de outras mutações conhecidas no gene SNCA, a variante rs3857059 também tem sido associada a várias doenças neurodegenerativas. Portanto, o objetivo do presente estudo foi o de procurar variante de associação e PD esporádica em pacientes mestiços mexicanos. Um estudo de caso-controle foi executado, incluindo 241 indivíduos, 106 pacientes e 135 controles saudáveis. A genotipagem foi realizada utilizando PCR em tempo real. A variante rs3857059 se mostrou associada a PD em mexicano-mestiços ( $O R=2,40, I C$ 1,1-5,1, $p=0,02)$ sob o modelo recessivo. Além disso, um efeito de gênero foi encontrado para o genótipo $G G$ no sexo feminino ( $O R=1,31, C l, 1,01-1,7, p=0,037)$. Este é o primeiro estudo que confirma associação da variante rs3857059 para a PD e também um efeito de gênero. Nossos dados contribuem para elucidar suscetibilidade à PD observada na população mexicana-mestiça.

Palavras-chave: doença de Parkinson; genes SNCA; genética.

Parkinson's disease (PD) is characterized by an accelerated loss of dopaminergic neurons of the substantia nigra pars compacta, which clinically expresses tremor, rigidity, bradykinesia, postural instability, and progressive impairment of cognitive function ${ }^{1}$. The $S N C A$ gene codifies a small protein called $\alpha$-synuclein, which has been largely involved in neurodegeneration processes; nevertheless, its function in health and disease remains unclear. Various hypotheses have been proposed regarding the pathogenicity of SNCA misfolding, because it aggregates as a key component of Lewy bodies found in PD. In the substantia nigra, neuronal cell loss occurs before symptoms develop, and accelerated cell loss may not always converge with $\alpha$-synuclein deposition. This raises the possibility of a functional, rather than anatomic, disturbance due to the abnormal expression of SNCA protein that occurs in neurodegeneration ${ }^{2}$. Multiple system atrophy (MSA)

\footnotetext{
${ }^{1}$ Instituto de Seguridad y Servicios Sociales de los Trabajadores del Estado, Centro Médico Nacional “20 de Noviembre”, México DF, México;

${ }^{2}$ Centro de Investigación Biomédica de Occidente, IMSS, Jalisco, México;

${ }^{3}$ Instituto de Ciencias Médicas y de la Nutrición Salvador Zubirán, México DF, México.

Correspondence: Luz Berenice López Hernández; División de Investigación Biomédica, Centro Médico Nacional 20 de Noviembre, Instituto de Seguridad y Servicios Sociales de los Trabajadores del Estado; San Lorenzo 502, C.P.03100, México DF, México. E-mail: lblhmedgen@gmail.com

Conflict of interest: There is no conflict of interest to declare.

Support: E015-2012 ISSSTE institutional program.

Received 05 February 2015; Received in final form 08 February 2016; Accepted 02 March 2016.
} 
and PD share the feature of deposition of abnormally phosphorylated $\alpha$-synuclein. A genome-wide association study of 1,713 white PD cases and 3,974 white control subjects also aimed to find significant associations with MSA. They identified an association with the SNCA locus in both diseases. The odds ratio (OR) associated with the heterozygous combination of the rs3857059 variant was 1.3 in both diseases (95\% confidence interval (CI) in PD: 1.2 to 1.5; 95\%CI in MSA: 1.1 to 1.6$)$, whereas the OR for homozygous carriers was 3.8 (95\%CI: 2.4 to 5.9) in PD and 5.9 (95\%CI: 3.2 to 10.9) in MSA ${ }^{3}$. The rs3857059 variant of the SNCA gene has also been associated with an elevated mRNA expression level in the temporal cortex biopsies of patients with Alzheimer's disease with Lewy body pathology ${ }^{4}$. There is increasing evidence that genetic variants in the SNCA locus demonstrate associations with PD in several studies conducted in different populations ${ }^{5,6,7}$. Moreover, triplication of SNCA is related to early onset of PD, whereas, when duplicated, it associates with classical presentation of PD. This suggests that gene dosage affects the onset and progression of the disease. A recent study in a cellular model carrying a SNCA gene triplication demonstrated decreased developmental fitness, accelerated aging, and increased neuronal cell loss $^{8}$. Besides copy number changes in the SNCA gene, three missense mutations are the most common pathogenic changes: A53T, A30P, and E46K 9 . Nevertheless, a previous work from our group demonstrated the absence of the A30P change in the subset of patients analyzed in our group. Hence, different genetic variants in the SNCA gene may represent a risk factor for PD development in our population. The aim of the present work was to assess the possible association of the rs3857059 variant of the SNCA gene and PD in Mexican Mestizo patients.

\section{METHOD}

In total, 241 Mexican Mestizos were included in the study. Allele frequencies were compared between 106 patients diagnosed with PD and 135 controls. Controls were clinical healthy participants that were referred for neurological evaluation by a certified neurologist (García S). Only participants with no family history of PD or other neurodegenerative disorders were included. Samples were obtained from participants between February 2009 and June 2010, from four tertiarycare level hospitals in Mexico (Neurology Departments from Centro Médico Nacional “20 de Noviembre”-ISSSTE, Instituto de Ciencias Médicas y de la Nutrición "Salvador Zubirán," Mexico City; and División de Genética, Centro de Investigación Biomédica de Occidente-IMSS, Jalisco, Mexico). Diagnosis was performed according to the Queen Square Brain Bank criteria ${ }^{10}$. Cognitive impairment was assessed using the Folstein Mini Mental State Examination Test. Institutional Committees approved the study and informed written consent was obtained from the participants.

Genomic DNA was isolated from peripheral blood leukocytes according to the method described by Gustincich et al. ${ }^{11}$; this technique allows high-quality DNA extraction for multiple applications due to the use of cationic detergents. Genotyping was performed by real time PCR using TaqMan probes (hydrolysis probes) specific for the rs3857059 (C_8933273_10 assay, Applied Biosystems, Foster City, CA, USA). Real-time PCR was performed on a LightCycler 480 II (Roche Diagnostics GmbH, Switzerland); PCR reactions were prepared according to the manufacturer's instructions. Statistical analysis was performed using SPSS software v. 18.0 (SPSS Inc., Chicago, IL, USA) and $\mathrm{p}<0.05$ were considered to indicate statistically significant results. Expected proportions of genotypes within each group were tested using the Hardy-Weinberg equilibrium (HWE), this was estimated using the $\chi 2$ test (available online http://ihg.gsf.de/cgi-bin/hw/hwal.pl). Allele and genotype frequencies were compared between groups using the $\chi 2$ test and Fisher's exact test. To test for an association between the rs3857059 and PD, the $\chi 2$ test was performed. To estimate the proportion of the $\mathrm{G}$ allele of the rs3857059 variant in each study group, OR were calculated from $2 \times 2$ contingency tables. The association of this variant was also tested by gender using the $2 \times 2 \chi 2$ test. To test for differences in the age at onset and the genotype frequencies of the variant of interest, we performed one-way ANOVA. Then a Student's t-test was performed to test for differences in the mean age of onset between GG/AG and AA genotype groups. A $\chi 2$ test was also performed to test for an association between the variant and cognitive impairment.

\section{RESULTS}

Allele frequencies in our study were similar to those reported by the MEX group in the HAPMAP database (http://hapmap.ncbi.nlm.nih.gov/). Alleles and genotypes were distributed according to HWE equilibrium in both groups, consistent with unequivocal genotyping, which is the main factor affecting HWE deviations ${ }^{12}$ (Table 1). The $\chi 2$ test revealed that the $\mathrm{G}$ allele in the homozygous state (recessive model) was associated with $\mathrm{PD}(\mathrm{OR}=2.40$, CI, 1.12 to $5.13, \mathrm{p}=0.02$ ) (Table 1 ). Correction by regression was not necessary because no confounding factors were found as per the definition of Clarke et al. ${ }^{13}$. To test for an association of the variant by gender, we performed $\chi 2$ tests to compare the GG, AG, and AA genotypes in males and females separately, and a difference was found in the female group $(\mathrm{p}<0.01)$ (Table 2$)$. The OR was estimated in females according to genotype in the following combinations: GG vs AA + AG using an allele positivity test table; association with PD was found only in females with the GG 
genotype $(\mathrm{OR}=1.31, \mathrm{CI}, 1.01$ to $1.7, \mathrm{p}=0.037)$. We further analyzed the possible involvement of the variant in cognitive impairment, age at onset, and early onset in the youngest group of patients (< 40 years old); no association was found with any of these features $(p>0.05)$ (Table 3$)$.

\section{DISCUSSION}

Allelic variants in various genes (PARK genes) have been linked to PD; for instance, the G2019S in the LRRK2 (PARK 8) gene confers major susceptibility to $\mathrm{PD}$ in Ashkenazi Jews and individuals from the north of Africa; whereas in Han Chinese populations, the rs7684318 variant of the SNCA gene (PARK1/4) was associated with PD but not with disease onset ${ }^{14}$. Therefore, major genes and specific variants associated with PD may be different among populations of distinct ethnic origin. Mexican Mestizos (most present-day Mexicans) are the result of the admixture of Spaniards and Amerindians ${ }^{15}$; therefore, genetic variants associated with PD may be not the same as those frequently reported in other populations. Some studies conducted in Mexican Mestizos have gained insights into populationspecific genetic variants associated with $\mathrm{PD}$, for example, the epsilon4 allele of $\mathrm{APOE}^{16}$ for late-onset $\mathrm{PD}$ and variants in GBA and PARK2 in early-onset PD ${ }^{17}$. Nonetheless, major susceptibility genes remain unknown ${ }^{18,19}$. Unlike in other ethnic groups, the A30P, IVS4 + 66A-G in SNCA, and other known point mutations in the PARK2 gene are uncommon in Mexican Mestizos ${ }^{18,20,21}$. The rs3857059 variant of the SNCA gene was associated with expression levels of SNCA mRNA in the temporal cortex of brain biopsies of patients with Alzheimer's \& Lewy Body pathology; homozygotes for the minor allele $(\mathrm{G})$ demonstrated significantly higher expression. Hence, we hypothesized that this genetic variant is associated with PD. To the best of our knowledge, this is the first study to find a positive association of the GG genotype of the rs3857059 variant and PD and also the first to find a gender effect, females with the GG genotype being more affected than males. Gender-based differences in gene

Table 1. Genotypes of the study groups.

\begin{tabular}{|c|c|c|c|c|c|}
\hline Groups & \multicolumn{3}{|c|}{ Genotypes (rs3857059) } & \multirow{2}{*}{$\begin{array}{c}\text { Association } \\
\text { OR, (Cl) }\end{array}$} & \multirow{2}{*}{$\begin{array}{c}\text { Significance } \\
\text { p-value }\end{array}$} \\
\hline SNCA analysis & AA & $A G$ & GG & & \\
\hline Controls $n=135$ & $48(35.6)$ & $67(49.6)$ & $20(14.8)$ & \multirow{2}{*}{$2.4(1.121-5.138)^{*}$} & \multirow{2}{*}{0.02} \\
\hline Patients $n=106$ & $25(23.6)$ & $56(52.8)$ & $25(23.6)$ & & \\
\hline
\end{tabular}

Table 2. Genotype frequencies in female and male groups of cases and controls.

\begin{tabular}{|c|c|c|c|c|c|c|c|}
\hline \multirow{2}{*}{ Genotype / Gender } & \multicolumn{3}{|c|}{ Case } & \multicolumn{3}{|c|}{ Control } & \multirow{2}{*}{ p-value (Fisher exact } \\
\hline & AA & $A G$ & GG & AA & $A G$ & GG & \\
\hline Female & 3 & 18 & 10 & 18 & 23 & 5 & $p=0.004$ \\
\hline Male & 22 & 38 & 15 & 30 & 44 & 15 & $p=0.815$ \\
\hline Total & \multicolumn{3}{|c|}{$n=106$} & \multicolumn{3}{|c|}{$n=135$} & $n=241$ \\
\hline
\end{tabular}

Table 3. Descriptive data for the study groups.

\begin{tabular}{|c|c|c|c|c|}
\hline \multicolumn{4}{|c|}{ Descriptive data of the groups of study } & \multirow[t]{2}{*}{ P-value (Fisher exact) } \\
\hline Age & Mean & Min & Max & \\
\hline Controls & $65.73 \pm 9.4$ & 40 & 88 & $p=0.02$ \\
\hline Patients & $62.52 \pm 12.1$ & 29 & 93 & \\
\hline Gender & Male & Female & & \\
\hline Controls & 89 & 46 & - & $p=0.48$ \\
\hline Patients & 75 & 31 & - & \\
\hline Smoking & Yes & No & - & \\
\hline Controls & 61 & 74 & - & $p=0.43$ \\
\hline Patients & 42 & 64 & - & \\
\hline Early onset* & Yes & No & & \\
\hline Number of Patients & 18 & 88 & - & - \\
\hline \multirow{2}{*}{ Age at onset } & Mean $\pm(S D)$ & Min & Max & Range \\
\hline & $56.26 \pm 14.4$ & 25 & 87 & 62 \\
\hline
\end{tabular}

SD: standard deviation; * Early onset was considered as symptoms < 40 years old; Percentage of early onset SPD 16.98\%. 
expression in human dopaminergic neurons of substantia nigra pars compacta exist ${ }^{22}$; however, SNCA upregulation was associated with $\mathrm{PD}$ in males ${ }^{22}$. In addition, methylation of the $S N C A$ gene and its abnormal expression have been linked to behavioral disorders in female ${ }^{23,24}$; therefore, further studies are mandatory to gain insights into the gender effect of the GG genotype of the rs3857059 variant and PD reported herein.

A recent report from our group demonstrated that the rs1801133 variant in the MTHFR gene was associated with $\mathrm{PD}^{25}$. MTHFR is involved in many different biochemical pathways in humans, such as DNA methylation.
The expression of the SNCA gene is regulated in part by methylation of intron 1 , because it was demonstrated in DNA derived from biopsies of substantia nigra, putamen, and cortex from PD patients ${ }^{26}$. Taken together, these findings suggest that, at least in Mexican Mestizos, allelic variants of the rs1801133 and rs3857059 in MTHFR and SNCA genes account for susceptibility to PD and the GG genotype of the rs3857059 variant is particularly associated with PD in females of this population. Further studies aimed to explore potential interactions between genetic and epigenetic changes involved in PD pathology may add to the complexity of this common neurodegenerative disorder.

\section{References}

1. Kim HJ. Alpha-synuclein expression in patients with Parkinson's disease: a clinician's perspective. Exp Neurobiol. 2013;22(2):77-83. doi:10.5607/en.2013.22.2.77

2. Bendor JT, Logan TP, Edwards RH. The function of $\alpha$-synuclein. Neuron. 2013;79(6):1044-66. doi:10.1016/j.neuron.2013.09.004

3. Scholz SW, Houlden H, Schulte C, Sharma M, Li A, Berg D et al. SNCA variants are associated with increased risk for multiple system atrophy. Ann Neurol. 2009;65(5):610-4. doi:10.1002/ana.21685

4. Linnertz C, Lutz MW, Ervin JF, Allen J, Miller NR, Welsh-Bohmer KA et al. The genetic contributions of SNCA and LRRK2 genes to Lewy Body pathology in Alzheimer's disease. Hum Mol Genet. 2014;23(18):4814-21. doi:10.1093/hmg/ddu196

5. Simón-Sánchez J, Schulte C, Bras JM, Sharma M, Gibbs JR, Berg D et al. Genome-wide association study reveals genetic risk underlying Parkinson's disease. Nat Genet. 2009;41(12):1308-12. doi:10.1038/ng.487

6. Liu J, Xiao Q, Wang Y, Xu ZM, Wang Y, Yang Q et al. Analysis of genome-wide association study-linked loci in Parkinson's disease of Mainland China. Mov Disord. 2013;28(13):1892-5. doi:10.1002/mds.25599

7. Ding H, Sarokhan AK, Roderick SS, Bakshi R, Maher NE, Ashourian P et al. Association of SNCA with Parkinson: replication in the Harvard NeuroDiscovery Center Biomarker Study. Mov Disord. 2011;26(12):2283-6. doi: 10.1002/mds.23934

8. Flierl A, Oliveira LM, Falomir-Lockhart LJ, Mak SK, Hesley J, Soldner F et al. Higher vulnerability and stress sensitivity of neuronal precursor cells carrying an alpha-synuclein gene triplication. PLoS One. 2014;9(11):e112413. doi:10.1371/journal.pone.0112413

9. Kanaan NM, Manfredsson FP. Loss of functional alpha-synuclein: a toxic event in Parkinson's disease? J Parkinsons Dis. 2012;2(4):249-67. doi:10.3233/JPD-012138

10. Hughes AJ, Daniel SE, Ben-Shlomo Y, Lees AJ. The accuracy of diagnosis of parkinsonian syndromes in a specialist movement disorder service. Brain. 2002;125(4):861-70. doi:10.1093/brain/awf080

11. Gustincich S, Manfioletti G, Del Sal G, Schneider C, Carninci P. A fast method for high-quality genomic DNA extraction from whole human blood. Biotechniques. 1991;11(3):298-300,302.

12. Sen S, Burmeister M. Hardy-Weinberg analysis of a large set of published association studies reveals genotyping error and a deficit of heterozygotes across multiple loci. Hum Genomics. 2008;3(1):36-52. doi:1479-7364-3-1-36

13. Clarke GM, Anderson CA, Pettersson FH, Cardon LR, Morris AP, Zondervan KT. Basic statistical analysis in genetic case-control studies. Nat Protoc. 2011;6(2):121-33. doi:10.1038/nprot.2010.182
14. Yu L, Xu P, He X, Hu F, Lin Z, Zhu M et al. SNP rs7684318 of the alpha-synuclein gene is associated with Parkinson's disease in the Han Chinese population. Brain Res. 2010;1346:262-5. doi:10.1016/j.brainres.2010.05.069

15. Rubi-Castellanos R, Martínez-Cortés G, Muñoz-Valle JF, González-Martín A, Cerda-Flores RM, Anaya-Palafox M et al. Pre-Hispanic Mesoamerican demography approximates the present-day ancestry of Mestizos throughout the territory of Mexico. Am J Phys Anthropol. 2009;139(3):284-94. doi:10.1002/ajpa.20980

16. Gallegos-Arreola MP, Figuera LE, Ortiz GG, Jiménez-Gil FJ, Ramírez-Vega J, Ruíz-Sandoval JL et al. Apolipoprotein E genotypes in Mexican patients with Parkinson's disease. Dis Markers. 2009;27(5):225-30. doi:10.1155/2009/617863

17. Gonzalez-Del Rincon ML, Monroy Jaramillo N, Suárez Martínez Al, Yescas Gómez P, Boll Woehrlen MC, López López M et al. The L444P GBA mutation is associated with early-onset Parkinson's disease in Mexican Mestizos. Clin Genet. 2013;84(4):386-7. doi:10.1111/cge.12084

18. Ramirez-Jirano LJ, Ruiz-Sandoval JL, Jiménez-Gil FJ, Ramírez-Vega $\mathrm{J}$, Vargas-Frutos E, Gallegos-Arreola MP et al. [Frequency of the IVS4+66A-G polymorphism in the alpha-synuclein gene in patients with Parkinson's disease in north-western Mexico]. Rev Neurol. 2007;44(1):15-7. Spanish.

19. García S, López-Hernández LB, Suarez-Cuenca JA, Solano-Rojas M, Gallegos-Arreola MP, Gama-Moreno 0 et al. Low prevalence of most frequent pathogenic variants of six PARK genes in sporadic Parkinson's disease. Folia Neuropathol. 2014;5(1)2:22-9. doi:10.5114/fn.2014.41741

20. Yescas P, López M, Monroy N, Boll MC, Rodríguez-Violante M, Rodriguez $U$ et al et al. Low frequency of common LRRK2 mutations in Mexican patients with Parkinson's disease. Neurosci Lett. 2010;485(2):79-82. doi:10.1016/j.neulet.2010.08.029

21. Martínez HR, González-González H, Cantú-Martínez L, Rangel-Guerra R, Hernández-Castillo CD, Vergara-Saavedra JJ et al. PARKIN-coding polymorphisms are not associated with Parkinson's disease in a population from northeastern Mexico. Neurosci Lett. 2010;468(3):264-6. doi:10.1016/j.neulet.2009.11.009

22. Cantuti-Castelvetri I, Keller-McGandy C, Bouzou B, Asteris G, Clark TW, Frosch MP et al. Effects of gender on nigral gene expression and Parkinson disease. Neurobiol Dis. 2007;26(3):606-14. doi:10.1016/j.nbd.2007.02.009

23. Frieling H, Gozner A, Römer KD, Wilhelm J, Hillemacher T, Kornhuber $\mathrm{J}$ et al. Alpha-synuclein mRNA levels correspond to beck depression inventory scores in females with eating disorders. Neuropsychobiology. 2008;58(1):48-52. doi:10.1159/000155991 
24. Frieling H Gozner A, Römer KD, Lenz B, Bönsch D, Wilhelm J et al. Global DNA hypomethylation and DNA hypermethylation of the alpha synuclein promoter in females with anorexia nervosa. Mol Psychiatry. 2007;12(3):229-30. doi:10.1038/sj.mp.4001931

25. García S, Coral-Vázquez R, Gallegos-Arreola MP, Montes-Almanza LA, Canto P, García-Martínez FA et al. Association of the rs1801133 variant in the MTHFR gene and sporadic Parkinson's disease. Folia Neuropathol. 2015;53(1):24-8. doi:10.5114/fn.2015.49971

26. Jowaed A, Schmitt I, Kaut O, Wüllner U. Methylation regulates alpha-synuclein expression and is decreased in Parkinson's disease patients' brains. J Neurosci. 2010;30(18):6355-9. doi:10.1523/JNEUROSCI.6119-09.2010 